\title{
Leader Member Exchange (LMX) and Followership Styles
}

\author{
A.K.D.N. Dilshani ${ }^{1}$ \\ ${ }^{1}$ Department of Business Management \\ Faculty of Business Studies \& Finance \\ Wayamba University of Sri Lanka \\ Kuliyapitiya \\ SRI LANKA \\ dilshani@wyb.ac.lk ${ }^{1}$
}

\begin{abstract}
The Leader Member Exchange (LMX) often has more ramifications for organizational results than a leader trait or behavior. LMX theory studies the quality of the relationship between the leader and each individual follower in a work unit. In certain instances, the styles of followers' is an ancestor for the formation of highquality LMX relationships. Five styles of followership styles have been described as alienated, conformist, passive, exemplary and pragmatic based on two behavioral dimensions of independent critical thinking and active engagement. How these followership styles relate with the formation of quality of LMX is an absent field in both relationship based approach to leadership and as well as followership literature. Accordingly, this investigation was carried out to fill this gap. Based on a purposeful sampling procedure, 200 newly graduated employees were selected. The main research instruments were questionnaires. The LMX 7 questionnaire was used to collect data regarding the quality of the relationship between leaders and followers, while Kelley's followership styles assessment and model was used to identify the followership styles of the respondents. Findings have shown that the existing level of LMX, active engagement and independent critical thinking behavior of newly graduated employees are not in a satisfactory. Further, active engagement behavior is closely linked with LMX as opposed to independent critical thinking behavior. Moreover, it was revealed that high quality LMX relationships were encountered by conformist and exemplary followership styles.
\end{abstract}

Keywords: Leader Member Exchange (LMX), Independent Critical Thinking, Active Engagement, Newly graduated employees, Sri Lanka

\section{INTRODUCTION}

The quality of a leader-follower dyadic relationship would be more predictive of positive organizational outcomes than traits or behaviors of superiors (Lussier and Achua, 2010). As a dyadic relationship tool, the leader-member exchange (LMX) theory has traditionally been regarded as a relevant and an important instrument for organizational management. LMX theory is a relationship-based approach to understanding how vertical dyads consisting of a leader (supervisor) and a member (subordinate) accomplish organizational tasks together 
(O'Donnell et al., 2012). LMX is at the heart of getting work done. The relationship between a supervisor and subordinate is a large factor in determining success, not only of the work-task, but also team and organizational performance

(Dulebohn et al., 2011).

Several researchers have posited that there is a positive relationship between LMX and many variables linked to organizational effectiveness including performance, communication, job satisfaction, and organizational climate. Conversely, LMX has also been linked to deleterious consequences including job dissatisfaction and burnout (Ngoma, 2011). In essence, LMX is about a work-related dyadic relationship that occurs between leader and each individual follower. Drawing on social exchange theory (Blau, 1964), the central premise of LMX theory is that leaders develop different types of exchange relationships with their followers, ranging from high quality to low quality, and the quality of these relationships affects important member attitudes and behaviors (Gerstner \& Day, 1997).

With some members, leaders develop high-quality exchanges that are characterized by mutual trust, loyalty, respect, and obligation. These are the "in-group". With others, they conduct low-quality interactions that rely on the formal employment - they are categorized as a member of "outgroup" (Graen \& Uhl-Bien, 1995). According to Lussier and Achua (2010) different kind of behavioral and situational factors such as follower attributes/ personality, leader and follower perceptions of each other and situational factors often influence to the creation of high or low quality LMX.

Like leaders, there are different types of followers. Based on individual characteristics, motivations, and behaviors, some followers may be more active and involved than others. While followership style itself is a significant concept to study, of more importance is how it relates to the creation of quality of LMX relationship. The rationality of this argument based on because leaders choose some specific followers to develop high-LMX than others. Due to the precocity of studies focus on this, researcher found a gap exist in study area in terms of theory and research context. Accordingly, this study is an initial attempt to bridge the knowledge gap by providing practical, theoretical and contextual contribution. The findings of this study would help to academicians and practitioners and as well as leaders and followers of organizations in determining how followership styles would contribute to develop high quality LMX which could be ultimately contribute to the organizational success by specially referring to the newly graduated employees in Kurunegala district in Sri Lanka.

\subsection{Objectives of the Study}

To investigate the level of leader member exchange (LMX) perceived by the newly graduated employees.

To investigate the level of critical thinking behavior perceived by the newly graduated employees. 
To investigate the level of active involvement behavior perceived by the newly graduated employees.

To investigate the most effective followership style which contributes to create high quality leader member exchange (LMX).

\section{LITERATURE REVIEW}

\section{The Leader-Member Exchange (LMX)}

The Leader-Member Exchange (LMX) theory that is emerged in the 1970s has evolved substantially (Graen, 1976; Graen and Scandura, 1987; Graen and Uhl-Bien, 1991). LMX theory proposes that, over time, leaders develop differentiated relationships with their subordinates and that the quality of these relationships has important implications for subordinate attitudes and behaviors (Gerstner \& Day, 1997). LMX research categorized the quality of the relationship between a leader and with their followers into two groups: the in-group and outgroup, more recently referred to as high-quality exchanges and lowquality exchanges respectively (Graen and Uhl-Bien, 1995). The in-group includes followers with strong social ties to their leader in a supportive relationship characterized by high mutual trust, respect, loyalty, and influence. Leaders primarily use expert, referent, and reward power to influence members of the in-group (Lussier and Achua, 2010). In contrast, leaders and followers in lowquality relationships closely adhere to their respective organizational roles and do not step beyond those bounds.
The benefits of high quality LMX relationships are numerous, including preferential treatment, increased jobrelated communication, differential allocation of formal and informal rewards, ample access to supervisors, and increased performance-related feedback (Graen and Uhl-Bien, 1995). Conversely, subordinates in low quality LMX relationships often experience the exact opposite; supervisors provide limited emotional support and trust and the subordinates receive few, if any, benefits outside the employment contract (Dienesch and Liden, 1986). This high quality/low quality exchange may have significant implications on the followership styles.

\section{Followership Styles}

The best conceptualization of followership styles is Kelley's model (Lussier and Achua, 2010). According to Kelley (1992) two dimensions describe the way that people follow. The first dimension is independent, critical thinking, versus dependent, uncritical thinking. Followers who are independent, critical thinkers consider the impact of their actions on the organization, they are willing to be inventive and offer constructive criticism in spite of the consequences (Mushonga \& Torrance, 2008). Dependent, uncritical thinkers on the other hand stick to the leader's thinking and only do what the leader tells them to do.

The second behavior variable-level of involvement-refers to the follower's willingness to be a visible and active participant. The opposite of this person is someone who is low on involvement. She or he is barely 
noticeable within the work unit (Lussier and Achua, 2010).

Based on the two dimensions stated above which describe characteristics of followers with different levels of thinking and engagement, Kelley (1992) identified five basic styles of followership that depend on how high or low the rank on the two dimensions is: alienated, passive, conformist, pragmatist and exemplary followers.

Alienated followers are capable independent thinkers but are less likely to engage in aspects of the organization. According to Kelley, this lack of engagement can actually occur through withdrawal from certain aspects of organizational life. Their independent thinking style allows them to evaluate the organization critically. At the same time, their analysis does not translate into action. They may have an idea concerning what should be done but do not act upon their impressions. Rather, they can become critical and launch disparaging appraisals of leadership and the organization (Leonard et al, 2011).

Unlike alienated followers, passive followers are dependent, uncritical thinking individuals who take a passive approach within the organization. Passive followers rank low on both independent and critical thinking and active engagement. They depend on leaders to do the thinking for them. They are unenthusiastic set of people who require constant supervision to complete assigned tasks. They are neither creative nor ambitious and are more likely to experience job fatigue (Kelley, 1988). For this reason, passive followers represent ineffective followers. It is typical of passive followers to avoid situations or tasks that require or force them to engage in independent thinking. In addition, they do not put in extra time to complete given tasks; they leave whether or not they have completed tasks when the day is over. Passive followers are prone to being easily swayed by manipulative leaders because they lack the courage to defend themselves or the organization (Oyetunji, 2013).

Opposite of alienated followers are conformist followers. These individuals tend to be actively engaged in the organization but do not have the capacity for or have forfeited independent thinking. Individuals at this level of followership trust in the leadership of the organization to think critically and make a decision for them. They have accepted the role of obedient worker, which is a role that traditional business managers seem to find compatible with their definition of good followers (Kellerman, 2008) Compared to alienated, passive and conformist followers, exemplary followers are independent, critical thinkers, innovative and willing to question the leadership. Exemplary followers rank high on both independent and critical thinking and active engagement. This type of follower is vital to organizational success because this followership style is ideal in many ways. Exemplary followers consider the consequences of tasks before they carry them out and excel in all tasks. They treat everyone in the organization the same way, get along very well with their colleagues (Bjugstad et al., 2006), provide 
support and intelligent criticism to the leader and even withdraw their support from an incompetent leader without disrupting the organization's operations. They stand to serve the best interest of the organization. Exemplary followers are likely to function very well in self-managed teams. They are a manager's best asset in the sense that they complement the leaders' efforts and can be depended upon to relieve the leader of many tasks (Mushonga \& Torrance, 2008).

Pragmatist followers have the capacity to think and act on their own, but they are limited in their ability to follow through. As followers, they perform the basic functions of their job or task, but do not move beyond essential behaviors needed to maintain average organizational performance. Safety in the organization is their main motivation (Leonard et al, 2011). When the organization is going through difficult situation, pragmatic followers do everything which is needed to get them through the crisis and not necessarily the organization. This characteristic is also affirmed by Lussier and Achua, (2010).

\section{METHODOLOGY}

The study adopted the deductive and quantitative approach in reaching research objectives. The unit of analysis was individuals who are the newly graduated employees and study was performed as a cross-sectional study. The target population represented the graduated employees (teachers, executive officers, engineers, and others) living in Kurunegala district in Sri Lanka, whose working experience is less than three years after their graduation. A total of 200 questionnaires were distributed across selected newly graduated employees, and 132 surveys were returned for an overall response rate of $66 \%$. The collected data were classified and coded for analysis. Statistical Packages for Social Science (SPSS, 20) version was used to analyze the data. Descriptive statistics, one sample T-test and correlation analysis were used

\section{Measures}

LMX: LMX 7 questionnaire developed by Graen \& Uhl-Bien (1995) was used to measure the perceived level of quality of relationship between participants and their supervisors. It is most commonly used by researchers to explore theoretical questions relating to mutual trust, respect, affection, support, loyalty etc. The scale consisted of 5 items.

Followership Personality: Kelley's (1992) followership styles assessment and model (KFAM) was developed to identify the different followership styles. The assessment consists of 20 items on a five-point scale for the follower to self-assess. The results categorize followership styles as passive, conformist, alienated, pragmatic, and exemplary.

\section{Hypotheses}

$\mathrm{HO}_{1}$ : Newly Graduated employees' perceived leader member exchange (LMX) is in a satisfactory level.

$\mathrm{HO}_{2}$ : Newly Graduated employees' critical thinking behavior is in a satisfactory level. 
$\mathrm{HO}_{3}$ : Newly Graduated employees' active involvement behavior is in a satisfactory level.

$\mathrm{HO}_{4}$ : Employees who demonstrate exemplary followership style record high quality leader member exchange (LMX) compared to employees indicating alienated, conformist, pragmatist, and passive styles of followership.

\section{RESULTS}

The demographic characteristics of the respondents are shown in table 1 . Accordingly 78 respondents were female $(59 \%)$, and 54 respondents were male (41\%). $34 \%$ of the participants' ages were between 20$29,57 \%$ of participants' ages were between 30-39, and $8 \%$ were over 40 years old. $42 \%$ of participants were bachelors. In terms of working experience, $36 \%$ of the respondents have less than 5 years working experience, $57 \%$ have $5-10$ years, and $7 \%$ have more than 10 years working experience.

Table 1. Demographic

\section{Characteristics of Respondents}

\begin{tabular}{|l|l|l|l|}
\hline Demographics & & N & $\%$ \\
\hline Gender & Female & 78 & 59 \\
\hline & Male & 54 & 41 \\
\hline Age & $20-29$ & 45 & 34 \\
\hline & $30-39$ & 76 & 57 \\
\hline & Over 40 & 11 & 09 \\
\hline Marital status & Not married & 56 & 42 \\
\hline & Married & 76 & 58 \\
\hline $\begin{array}{l}\text { Working } \\
\text { experience }\end{array}$ & $\begin{array}{l}\text { Less than 5 } \\
\text { years }\end{array}$ & 48 & 36 \\
\hline & $\begin{array}{l}\text { Between 5 and } \\
10 \text { years }\end{array}$ & 75 & 57 \\
\hline & Over 10 years & 9 & 7 \\
\hline
\end{tabular}

\section{Followership Types}

Table 2 shows the information regarding the newly graduated employees' followership style.

Table 2. Exhibited Followership Styles of Newly Graduated Employees.

\begin{tabular}{|l|l|l|}
\hline $\begin{array}{l}\text { Followership } \\
\text { Style }\end{array}$ & Frequency & Percentage \\
\hline Alienated & 27 & 21.9 \\
\hline Exemplary & 21 & 15.9 \\
\hline Pragmatic & 46 & 34.8 \\
\hline Passive & 9 & 6.8 \\
\hline Conformist & 29 & 20.6 \\
\hline Total & 132 & 100 \\
\hline
\end{tabular}

As per table 2, frequency and percentage were used to identify the graduated employees' followership styles. The majority (34.8\%) of the participants acted as pragmatic follower, $21.9 \%$ of the participants acted as alienated follower, $20.6 \%$ of them were conformist followers, $15.6 \%$ were exemplary followers and $6.8 \%$ of the participants acted as passive follower.

\section{The Degree of LMX Relationship}

The degree of LMX relationship was measured by using the guidelines provided by Graen \& Uhi-Bien (1995). Table 3 provides information about the quality of the leader member exchange relationship perceived by the respondents. Frequency and percentage were used to identify such dyadic relationship. 
Table 3. The Degree of LMX

\begin{tabular}{|l|l|l|}
\hline $\begin{array}{l}\text { Degree of } \\
\text { Relationship }\end{array}$ & Frequency & Percentage \\
\hline $\begin{array}{l}\text { High Quality } \\
\text { LMX }\end{array}$ & 60 & 45.5 \\
\hline $\begin{array}{l}\text { Low Quality } \\
\text { LMX }\end{array}$ & 72 & 54.5 \\
\hline Total & 132 & 100 \\
\hline
\end{tabular}

It was revealed that majority $(54.5 \%)$ of participants perceived low quality relationship with his/her manager.

\section{Preliminary Analyses}

The assumption of univariate and bivariate normality was tested for the KFAM and LMX-7. One-Sample Kolmogorov-Smirnov Test (K-S) was used to test the null hypothesis that the variable is normally distributed. It was found that the K-S test is not significant (0.960); thus, cannot reject the null hypothesis and may assume that data is normally distributed. The histogram was symmetrical, skewness (-.62) and kurtosis (-.11) were within +/- 1.00 tolerance (Meyers, Gamst, \& Guarino, 2013). The Q-Q normality plot, which is the plot of each observed value with the expected value if the distribution were normal, showed that plotted values did not depart significantly from a straight diagonal line, thereby indicating that the scores were considered normally distributed. Internal consistency reliabilities of the two instruments were also tested. KFAM recorded Cronbach's $\alpha=.81$, while LMX-7 revealed Cronbach's $\alpha$ $=.86$ which suggests that the internal reliability of the instrument is satisfactory.

\section{Primary Analyses}

To test the hypothesis 01 (Newly graduated employees' perceived leader member exchange (LMX) is in a satisfactory level) study applied the One- Sample T Test to detect the level of LMX perceived by newly graduated employees.

Table 4. T test results (One- Sample $T$ Test) to detect the level of perceived quality of leader member exchange (LMX)

\begin{tabular}{|l|l|l|l|l|l|}
\hline & Mean & SD & df & $\begin{array}{l}\text { t- } \\
\text { value }\end{array}$ & $\begin{array}{l}\text { Signifi } \\
\text { cance }\end{array}$ \\
\cline { 2 - 6 } LMX & 3.24 & 0.47 & 194 & 2.26 & 0.00 \\
\hline
\end{tabular}

The table shows that the value of (T) is positive and stood at (2.264) and statistically significant and (0.00), where general mean value compared to the standard value of the Likert 5 Scale, namely, (3.24), and the results statistically confirmed that newly graduated employees' perceived leader member exchange (LMX) is not in a satisfactory level

The result of the One Sample T Test to detect the hypothesis 02 (Newly Graduated employees' critical thinking behavior is in a satisfactory level) is shown by following table.

Table 5. T test results (One- Sample $T$ Test) to detect the level of critical thinking behavior

\begin{tabular}{|c|c|c|c|c|c|}
\hline & Mean & $\mathrm{SD}$ & $\mathrm{df}$ & $\begin{array}{l}\text { t- } \\
\text { value }\end{array}$ & $\begin{array}{l}\text { Sign } \\
\text { fican } \\
\text { ce }\end{array}$ \\
\hline & 3.58 & 0.69 & 207 & 3.19 & 0.00 \\
\hline
\end{tabular}


The table shows that the value of $(\mathrm{T})$ is positive and stood at (3.189) and statistically significant and (0.00), where general mean value compared to the standard value (4) of the Likert 5 Scale, namely, (3.58), and the results statistically confirmed that newly graduated employees' critical thinking behavior is not in a satisfactory level.

The result of the One Sample T Test to detect the hypothesis 03 (Newly Graduated employees' active involvement behavior is in a satisfactory level), is shown by following table.

Table 6. T test results (One- Sample $T$ Test) to detect the level of active engagement behavior

\begin{tabular}{|l|l|l|l|l|l|}
\hline $\begin{array}{l}\text { Active } \\
\text { Engagem } \\
\text { ent }\end{array}$ & Mean & SD & df & $\begin{array}{l}\text { t- } \\
\text { valu } \\
\text { e }\end{array}$ & $\begin{array}{l}\text { Sign } \\
\text { ifica } \\
\text { Behavior }\end{array}$ \\
\cline { 2 - 6 } & 3.89 & 0.53 & 178 & 2.91 & 0.00 \\
\hline
\end{tabular}

The table shows that the value of (T) is positive and stood at (2.908) and statistically significant and (0.00), where general mean value compared to the standard value (4) of the Likert 5 Scale, namely, (3.89), and the results statistically confirmed that newly graduated employees' critical thinking behavior is not in a satisfactory level

Correlation analysis was used to measure the degree of relationship between leader member exchange and followership styles. The correlation coefficients and relevant $\mathrm{P}$ values received by each relationship are shown in table 7 . These values were used to determine the relationship and the significance of the relationships existing among the variables.
Table 7. Matrix of Inter Correlations

\begin{tabular}{|l|l|}
\hline Variable & LMX \\
\hline 1. Active engagement & $0.77^{* * *}$ \\
\hline 2.Independent critical thinking & $0.61^{* *}$ \\
\hline 3. Alienated followership & 0.38 \\
\hline 4. Conformist & $0.79^{* * *}$ \\
\hline 5. Passive & 0.25 \\
\hline 6. Exemplary & $0.82^{* * *}$ \\
\hline 7. Pragmatic & 0.47 \\
\hline
\end{tabular}

*** Correlation is Very Strong at the 0.01 level (2-tailed)

** Correlation is Very Substantial at the 0.01 level (2-tailed).

According to Connolly and Sluckin (1962) the $r$ value of $0.9-1.00$ shows the positive and strong relationships, 0.7 - 0.9 shows good relationships, 0.4 - 0.7 shows the moderate relationships, $0.2-0.4$ shows the low relationships and the value less than 0.2 shows the weak relationships.

As shown in Table 7, when comparing to the two dimensions of independent, critical thinking and active engagement, it was revealed that active engagement $(r=.0 .77, \mathrm{p}<0.05)$ was related to LMX and the relationship was good. Further, independent critical thinking $(\mathrm{r}=$ $.0 .61, \mathrm{p}<0.05)$ was moderately related to LMX. This was statistically proven that leaders tend to develop high LMX with the followers who are willing to be a visible and actively participate than the followers who are capable in examine, analyze, and evaluate matters of significance in the organization's life. 
Moreover, it was revealed that exemplary followership style $(\mathrm{r}=$ $.0 .82, \mathrm{p}<0.05$ ) was related to LMX and the relationship was good. This means that exemplary followers often recorded high level of leader member exchange than other followership types. Further, results also revealed that conformist followership style was highly correlated to LMX ( $r=0.79, p$ $<0.05$ ), and the relationship was good. Pragmatic followership style $(r=0.47$, $\mathrm{p}<0.05)$ was moderately related to LMX, the relationship was significant. Alienated and passive followership styles recorded low relationship with LMX. Based on above results it is statistically proven that exemplary followership type is highly correlated with quality of leader-member exchange (LMX) than the other followership types of alienated, pragmatic, conformist and passive. Hypothesis $\mathrm{H}_{4}$ is then accepted.

\section{CONCLUSION}

The findings showed that the active engagement level of newly graduating employees is higher than their independent/critical level of thinking. However both active engagement and independent critical thinking behavior are not at a satisfying level. It can also be noticed that the relationship between active engagement and LMX is relatively strong compared to the correlation between independent, critical thinking and LMX. Since independent critical thinkers often have more critical opinions on decision-making by leaders, and can question, disagree, or condemn them, there is possibility for leaders to welcome followers who are actively participating to the execution of decisions taken by them.

Based on Kelley's (1992) theory, exemplary followers are high on critical thinking and active engagement. This group of employees has more than their usual work criteria. They are engaging their practices with passion. They are risktakers who have the willingness to initiate reform and put themselves at risk or in confrontation with others, including their leaders, in order to strengthen their organization. They are engaged in daily life and readily give positive criticism not only to their subordinates or colleagues, but also to their superiors. In the corporate environment, they are known to be the greatest resource of any organization, since they are an accessory to the leadership's activities and can be counted upon to relieve the leader of certain duties. The results show that 15.9 per cent of newly graduated employees who participated in the study are in this category. The findings suggest that this type of followership is strongly associated with the highquality LMX. Followers who report high-quality LMX for their superiors earn various advantages, including preferential treatment, improved jobrelated coordination, differential sharing of formal and informal incentives, comprehensive access to superiors, and enhanced performancerelated input (Graen and Uhl-Bien, 1995). There is no question that the extemporary follower records highquality LMX with his/her leader as his/her job success standard should be exceptional. They are loyal to the organization and look beyond themselves, and their efforts should 
have a positive effect on the organization (Oyetungi, 2013).

Conformist followers tend to be actively engaged in the organization but do not have the capacity for or have forfeited independent thinking. Individuals at this level of followership trust in the leadership of the organization to think critically and make decisions for them. They have accepted the role of obedient worker, which is a role that traditional business managers seem to find compatible with their definition of good followers (Kellerman, 2008). The findings indicate that $20.6 \%$ of newly graduated employees who participated in the study are in this group and record significant correlation with LMX. Since conformists are always obedient to their leaders, high probability is there that leaders develop high LMX with those followers even though they are lacking in independent critical thinking.

According to Kelley's (1992) theory, pragmatist followership style is eclectic, it exhibits a little of conformist, alienated, passive and exemplary followership styles. The findings of this study revealed that majority of newly graduated employees $(34.8 \%)$ are in this category. The implication of this is that they are "stuck in the middle" most of the time. Because it is difficult to discern just where they stand on issues, they present an ambiguous image, with positive and negative sides (Lussier and Achua, 2010).They are merely doing the minimum to get themselves sustained on their jobs, and they are not all that passionate about the vision of the organization and that of the nation itself (Oyetungi,
2013). Study revealed that pragmatic followers record moderate quality relationship with their leaders.

Going by Kelley's (1992) theory, alienated followers are aloof from of the organization, since they feel cheated or unappreciated by his organization for outstanding work. They are ready, but not inclined, to use their competence to develop solutions to problems. The results of this study reveal that $21.9 \%$ of the participants are in this group. According to Kelley (1992), this absence of dedication will potentially arise by withdrawing from certain facets of organizational life. Their independent thinking style helps them to objectively analyze the organization. Around the same time, their analysis is not put into effect. They may have an understanding of what needs to be done, but they do not act on their experiences. Rather, they may become critical and elicit disparaging evaluations of the leadership and the organization. The research confirms poor LMX with alienated followers by confirming Kelly's theory.

The findings of this study showed that the followership styles of the majority of graduates are pragmatic. Alienated and passive followership styles were not linked to the development of highquality member exchange (LMX). Efficient followership style was closely linked to the development of a high-quality leader member exchange (LMX) suggesting that leaders build high quality relationships with followers who show high expertise in job skills, interpersonal skills and value components.

In order to be successful as a follower, it is crucial to learn the skills required 
to balance two opposing roles of follower; respectively, to execute decisions taken by the leader and to pose concerns about certain decisions when they are perceived to be false or immoral. While not always realistic, supporters must be able to risk the leader's displeasure with this criticism. Moral dignity and ability to take a stand on the basis of principle distinguish the traits of a successful follower (Lussier and Achua, 2004). Developing a high-quality LMX through mutual trust and respect between the leader and the follower can offer mutual benefits.

Compared to those who have poor relations with their leaders, highquality exchanges appear to gain widespread social, political and economic assistance, indicating that these people will not only be happy with their employment assignments, but will also go beyond their formal job criteria to validate and reimburse such treatment (Erdogan and Enders, 2007). In the other hand, subordinates in a high-quality LMX relationship prefer to gain more support and career assistance, such as preparation and professional growth opportunities. Such resources and support will enhance the self-development and development of skills of subordinates, boost their job performance and reduce their work pressure (Jongsoo, 2013).

The low satisfactory level of independent critical thinking behavior and active engagement behavior of newly graduated employees suggests that the Sri Lankan higher education system pays little attention to the development of industry-needed graduates. As Dyllick (2015) pointed out there are significant questions regarding the capacity of higher education institutions to provide students with the skills required to work in contemporary organizations and to train them for the technical demands and challenges of globalized industry in a pluralistic environment. One of the biggest critiques of state universities is the consistency and importance of education to job security. As a result, state university education has not provided the country with a workforce ready to face the challenges of a dynamic marketoriented economy (World Bank, 2010). While technical and professional subjects in the fields of medicine, engineering, general sciences, management and law have been introduced to the universities, there was a mismatch between the skill demands of private sector and the supply of universities (Ranasinghe, 1992). It is also important to consider the methods implemented to address these demands and how attitudinal improvements are incorporated in the higher education sector in order to improve efficiency and responsiveness. Furthermore in today's world, it might not be enough to equip workforce with the potential to be employable. They will need capabilities to consistently update their skills for potential employability (Wickramasinghe, 2018).

There are several drawbacks in this study. First, data for review were obtained using arbitrary scales and self-reports that could misrepresent the correlation between constructs. And self-reported data is subject to a standard form of variance. Another 
drawback was that this research was limited to newly graduated employees in Kurunegala district of Sri Lanka. The participants differed in role, duties, responsibilities, and even skills. It is important to overcome generalization issues by undertaking research in other districts/provinces and other communities.

\section{REFERENCES}

Bjugstad, K., Thach, E.C., Thompson, K.J., \& Morris, A. (2006). A Fresh Look at Followership: A Model for Matching Followership and Leadership Styles. Journal of Behavioral and Applied Management, 7(3), 304-319.

Blau, P. M. (1964). Exchange and power in social life. New York: John Wiley.

Connolly, T.G. and Sluckin, W. (1962). An Introduction to Statistics for Behavioral Science. ( $2^{\text {nd }}$ edition), London: CleaverHuman Press.

Dienesch, R.M., \& Liden, R.C. (1986). Leader-.member exchange model of leadership: A critique and further development. Academy of Management Review, 11, 618-634.

Dulebohn, J.H., Bommer, W.H., Liden, R.C., Brouer, R.L., \& Ferris, G. R. (2011). A metaanalysis of antecedents and consequences of leader-member exchange: Integrating the past with an eye toward the future. Journal of Management, 38, 1715-1759.
Dyllick, T. (2015). Responsible management education for a sustainable world: The challenges for business schools. Journal of Management Development, 34(1), 16-33.

Erdogan, B., \& Enders, J. (2007). Support from the top: Supervisors' perceived organizational support as a moderator of leader-member exchange to satisfaction and performance relationships. Journal of Applied Psychology, 92(2), 321-30.

Gerstner C.R., \& Day, D. V. (1997). Meta-analytic review of leadermember exchange theory: correlates and construct issues. Journal of Personal Selling \& Sales Management, 18 (3), 85-87.

Graen, G.B. (1976). Role making processes within complex organizations. In: M.D. Dunnette (Ed.), Handbook of Industrial and Organizational Psychology, Chicago: Rand-McNally, 12011245.

Graen, G.B., \& Scandura, T. (1987). Toward a psychology of dyadic organizing. In: B. Staw \& L.L. Cumming (Eds.), Research in Organizational Behavior, Greenwich, CT: JAI Press, 9, 175208.

Graen, G.B., \& Uhl-Bien, M. (1991a). The transformation of professionals into self-managing and partially self-designing contributions: Toward a theory of leader-making. Journal of 
Management Systems, 3(3), 3348.

Graen, G.B. and Uhl-Bien, M. (1995). Relationship-based approach to leadership: development of leader-member exchange (LMX) theory of leadership over 25 years: applying a multi-level multidomain perspective. Leadership Quarterly, 6(2), 219-247.

Kellerman, B. (2008). Followership: How followers are creating change and changing leaders. Bolton: Harvard Business Press.

Kelley, R.E. (1992). The power of followership: How to create leaders people want to follow and followers who want to lead themselves. NY: Doubleday Currency.

Kelley, R.E. (1988). In Praise of Followers. Harvard Business Review, 66(6), 142-148.

Leonard, D.J., Moons, W.G., Mackie, D.M., \& Smith, E.R. (2011). We're mad as hell and we're not going to take it anymore: Anger self-stereotyping and collective action. Group Processes and Intergroup Relations, 14, 99-111.

Lussier, R.N., \& Achua, C.F. (2010). Leadership: Theory Application \& Skill Development. $4^{\text {th }}$ Edition, USA, Cengage Learning.

Mushonga, S.M., \& Torrance, C.G. (2008). Assessing the relationship between followership and the Big Five factor model of personality. Review of Business Research, 8, 185-193.
Meyers, L.S., Gamst, G. \& Guarino, A.J. (2013). Applied Multivariate Research: Design and Interpretation. $\quad 2^{\text {nd }}$ Edition, London, UK: Sage Publications, Inc.

Ngoma, S. (2011). The Impact of Leader-Member Exchange Theory on Education: Leveraging the Power of 'In-Group' and 'OutGroup' to Enhance School Effectiveness. Paper to contributing to the body of research on LMX in education. WA Nkhoma

O'Donnell M., Yukl, G. \& Taber, T. (2012). Leader behavior and LMX: A constructive replication. Journal of Managerial Psychology, 27 (2).

Oyetunji, C.O. (2013). The Relationship between Followership Style and Job Performance in Botswana Private Universities. International Education Studies, 6 (2).

Ranasinghe, S. W. (1992). Human resource development in Sri Lanka: Present trends and future perspectives. In S. Salleh \& S. B. Gurung (Eds.), Human Resource Development in South Asia. Malaysia: Asian and Pacific Development Centre.

Wickramasinghe, V. (2018). Higher education in state universities in Sri Lanka - review of higher education since colonial past through international funding for development. International Journal of Educational Management, 32(3), 463-478, 
https://doi.org/10.1108/IJEM-012017-0028.

World Bank (2010), Project appraisal document on a proposed credit in the amount of SDR 25.6 Million (US\$40 Million equivalent) to the Democratic Socialist Republic of Sri Lanka for a Higher Education for the Twenty-First Century Project. Report No: 49190-LK, Washington D.C.: The World Bank. 